\title{
Control of NK Cell Activation by Immune Checkpoint Molecules
}

\author{
Asma Beldi-Ferchiou ${ }^{1}$ and Sophie Caillat-Zucman ${ }^{2,3, *}$ \\ 1 Laboratoire d'Immunologie, Hôpital Henri Mondor, Assistance Publique-Hôpitaux de Paris, 94000 Créteil, \\ France; asma.ferchiou@aphp.fr \\ 2 Centre de Recherches sur l'Inflammation, Institut National de Recherche Médicale (INSERM) UMR1149, \\ Université Paris Diderot, 75013 Paris, France \\ 3 Laboratoire d'Immunologie, Hôpital Saint-Louis, Assistance Publique-Hôpitaux de Paris, \\ 75010 Paris, France \\ * Correspondence: sophie.caillat@inserm.fr; Tel.: +33-1-4249-9219
}

Received: 19 September 2017; Accepted: 9 October 2017; Published: 12 October 2017

\begin{abstract}
The development of cancer and chronic infections is facilitated by many subversion mechanisms, among which enhanced expression of immune checkpoints molecules, such as programmed death-1 (PD-1) and cytotoxic T lymphocyte-associated antigen 4 (CTLA-4), on exhausted $\mathrm{T}$ cells. Recently, immune checkpoint inhibitors have shown remarkable efficiency in the treatment of a number of cancers. However, expression of immune checkpoints on natural killer (NK) cells and its functional consequences on NK cell effector functions are much less explored. In this review, we focus on the current knowledge on expression of various immune checkpoints in NK cells, how it can alter NK cell-mediated cytotoxicity and cytokine production. Dissecting the role of these inhibitory mechanisms in NK cells is critical for the full understanding of the mode of action of immunotherapies using checkpoint inhibitors in the treatment of cancers and chronic infections.
\end{abstract}

Keywords: NK cells; immune checkpoint molecules; cancer immunotherapy

\section{Introduction}

Natural killer (NK) cells are key players in the elimination of cells that have undergone infection, malignant transformation, or even physical or chemical damage [1-5]. In contrast to T or B lymphocytes, reactivity of NK cells toward their targets does not require prior sensitization and is not dependent on a single dominant receptor. Actually, NK cells are equipped with a large repertoire of germline-encoded activating and inhibitory receptors [1,4,6-9]. Integration of all signals transmitted by these receptors tightly regulates NK-cell behavior and ultimately determines the magnitude of NK-cell-mediated cytotoxicity and cytokine production [7-9].

Inhibitory receptors such as killer cell Ig-like receptors (KIRs) and natural killer cell receptor group 2 member A CD94/NKG2A heterodimer recognize major histocompatibility complex (MHC) class I molecules. Since these molecules are ubiquitously expressed on most healthy normal cells, their interaction with NK-cell inhibitory receptors ensures that NK cells are kept in calm in physiological condition. Consequently, cells with reduced MHC class I expression, a situation frequently observed during the course of tumors or viral infections, do not provide enough inhibitory signals and thus, become sensitive targets for NK-cell mediated killing [10-12]. To become fully competent, NK cells undergo an education process during their development to ensure that only those that successfully engage their inhibitory receptors with the cognate host's MHC class I molecules become functionally mature. This kind of "central" tolerance mechanism sets the triggering threshold of individual NK cells in order to prevent reactivity against self $[10,13,14]$. 
Beside inhibitory receptors, NK cells express panoply of activating receptors that recognize a large spectrum of ligands usually absent from the surface of healthy cells, such as tumor/viral-derived proteins or stress-induced molecules. Upon engagement by their cognate ligands, NK cell activating receptors trigger target cell lysis and release of pro-inflammatory cytokines (IFN- $\gamma$, TNF- $\alpha$ ) $[4,6,15,16]$. NK cells are also equipped with the CD16 molecule (Fc $\gamma$ RIIIA), which allows Antibody-dependent cellular cytotoxicity (ADCC) upon recognition of IgG antibody-coated target cells. Depending on their relative surface expression of the CD56 and CD16 molecules, NK cells are distinguished into two major subsets, CD56 $6^{\text {bright }} \mathrm{CD} 16^{-}$cells (around 10\% of peripheral blood NK cells) and the most mature $\mathrm{CD} 56^{\mathrm{dim}} \mathrm{CD} 16^{+}$cell subset. These two subsets are associated with different expression of some receptors, in particular KIR and CD94/NKG2A, and distinct functional capabilities [17-19].

NK cells are not only "killer cells", albeit they were originally discovered thanks to their ability to spontaneously kill tumor cells. Indeed, through their ability to produce various soluble factors, NK cells interact with other immune cells and help promoting the development of efficient adaptive immune responses [20-22].

Thanks to their intrinsic properties, NK cells have entailed growing interest as promising therapeutic strategies to enhance immune surveillance in patients with cancer and infectious diseases. As such, their usage is already effective in the field of hematopoietic malignancies [23-25]. Accumulating evidence show that defects in NK cell function or number are associated with an increased susceptibility to develop viral infections and cancer [26,27]. In some cancers, quantitative NK-cell deficiency correlates with poor clinical outcomes [28]. Moreover, the development of chronic infections and cancers is facilitated by various immune subversion mechanisms targeting NK cell effector functions, such as the production of regulatory cytokines or immunosuppressive factors, decreased expression of activating receptors or their ligands, and expression of immune checkpoint molecules [29-34].

Immune checkpoint molecules are proteins that help keep immune responses in check, and thus can prevent immune cells, in particular T cells, from killing cancer cells. When the immune checkpoints are blocked, the brakes on the immune response are released, and T cells become able to kill cancer cells. Recently, targeting immune checkpoints with specific inhibitor antibodies has revolutionized the treatment of many cancers [35-37]. The main goal of such therapeutic strategies is to reverse exhaustion of $\mathrm{T}$ cells and reinvigorate their functional capacities. While enhanced expression of immune checkpoints such as programmed death-1 (PD-1), cytotoxic T lymphocyte-associated antigen 4 (CTLA-4), T cell immunoglobulin- and mucin-domain 3 (TIM-3), and lymphocyte activation gene-3 (LAG-3) has been largely demonstrated to decrease $\mathrm{T}$ cell functions, their expression and functional consequences in NK cells are much less explored. In this review, we focus on the current state of the art on expression of immune checkpoint molecules on NK cells and how it can interfere with NK cell functions. We also discuss how KIRs and CD94/NKG2A inhibitory receptors, although not classically defined as immune checkpoint molecules, modulate the duration and magnitude of NK cell responses and thus, recently emerged as promising targets for the treatment of cancer. For purpose of clarity, a summary of the immune checkpoint molecules, their expression and cognate ligands, and their major impact on NK cell functions is given in Table 1. 
Table 1. Overview of immune checkpoint molecules expressed on natural killer (NK) cells: pattern of expression, ligands, and impact on NK cell functions.

\begin{tabular}{|c|c|c|c|}
\hline $\begin{array}{l}\text { Inhibitory Immune } \\
\text { Checkpoint }\end{array}$ & Expression & Ligands & $\begin{array}{c}\text { Direct Impact on NK } \\
\text { Cell Functions }\end{array}$ \\
\hline PD-1 & $\begin{array}{l}\text { Activated T and B cells, } \\
\text { NK cells, natural killer T } \\
\text { (NKT) cells, ILC-2 cells } \\
\text { and myeloid cells. }\end{array}$ & $\begin{array}{l}\text { PD-L1 (B7-H1) and } \\
\text { PD-L2 (B7-DC) }\end{array}$ & $\begin{array}{c}\text { Inhibition of NK cell cytolytic } \\
\text { activity and cytokine } \\
\text { production. }\end{array}$ \\
\hline CTLA-4 & $\begin{array}{c}\text { Treg cells, } \\
\text { Activated T and B cells, } \\
\text { Activated mouse NK cells, } \\
\text { Human NK cells? }\end{array}$ & B7-1 and B7-2 & $\begin{array}{l}\text { Inhibition of mouse NK-cell } \\
\text { IFN- } \gamma \text { production. } \\
\text { Direct effect on human NK cells } \\
\text { not documented. }\end{array}$ \\
\hline TIM-3 & $\begin{array}{l}\text { NK, T, NKT and } \\
\text { myeloid cells. }\end{array}$ & $\begin{array}{l}\text { Galectin-9 } \\
\text { HMGB1 } \\
\text { CEACAM1 }\end{array}$ & $\begin{array}{l}\text { Dual role (inhibition/activation } \\
\text { of NK cell functions) } \\
\text { depending on the experimental } \\
\text { or clinical setting. }\end{array}$ \\
\hline $\begin{array}{c}\text { T Cell } \\
\text { Immunoglobulin and } \\
\text { ITIM Domain (TIGIT) }\end{array}$ & NK cells, T cells. & $\begin{array}{l}\text { CD112 (PVRL2) } \\
\text { CD155 (PVR) }\end{array}$ & Inhibition of NK cell functions. \\
\hline LAG-3 & $\begin{array}{l}\text { Activated T and NK cells, } \\
\text { Treg, B cells, plasmacytoid } \\
\text { dendritic cell (DC), NKT. }\end{array}$ & MHC class II molecules & $\begin{array}{c}\text { The impact of LAG-3 on NK cell } \\
\text { functions is controversial and } \\
\text { not well documented. }\end{array}$ \\
\hline Inhibitory KIRs & NK cells, CD8 T cells. & MHC class I molecules & Inhibition of NK cell functions. \\
\hline NKG2A & NK cells, CD8 T cells. & $\begin{array}{l}\text { HLA-E (non-classical } \\
\text { MHC class I molecule) }\end{array}$ & Inhibition of NK cell functions. \\
\hline
\end{tabular}

\section{Programmed Cell Death-1}

PD-1 is an immune checkpoint inhibitory receptor expressed on activated $\mathrm{T}$ and $\mathrm{B}$ lymphocytes. PD-1 binds the PD-L1 and PD-L2 ligands, which are expressed on tumors, infected cells, and on antigen presenting cells present in inflammatory infiltrates [38-41]. PD-1 is involved in terminating immune responses of antigen-stimulated $\mathrm{T}$ and $\mathrm{B}$ cells, thus contributing to the normal autoregulatory machinery. PD-1 regulates immune tolerance, as indicated by the occurrence of autoimmune diseases in PD-1 deficient mice [42,43] and by the association of PD-1 polymorphisms with susceptibility to various human autoimmune diseases [44-46]. Moreover, autoimmune manifestations are frequently observed as a side effect of PD-1 blockade strategies in the clinic $[47,48]$. In antigen-stimulated T cells, binding of PD-1 to its ligands leads to abrogation of the T cell receptor (TCR) signaling and subsequent inhibition of $\mathrm{T}$ cell functions [49-52]. Thus, the PD-1 axis plays an important role in limiting antigen-specific responses. This protective mechanism is frequently exploited by tumors and viruses to escape immune response. After repeated TCR stimulation during chronic viral infection or in the cancer microenvironment, PD-1 is persistently upregulated on virus- or tumor-specific T cells. Consequently, PD-1 receptor/ligand interactions hamper T-cell activation and effector functions, and ultimately result in T lymphocyte exhaustion [53,54]. Importantly, blockade of the PD-1 pathway can rescue PD- $1^{+} \mathrm{T}$ cells from exhaustion and reinvigorate their effector capacities. Therapeutic strategies that target the PD-1/PD-L1 interactions have recently shown remarkable clinical responses in patients with various cancer types [36,55-57]. The efficiency of such therapies is considered to largely rely on the enhanced effector functions of tumor-specific $T$ cells.

In addition to $\mathrm{T}$ and $\mathrm{B}$ lymphocytes, expression of PD-1 was reported in innate or innate-like immune cells, such as NKT [58] cells and group 2 innate lymphoid cells (ILC-2) [59]. In NK cells, expression of PD-1 was reported in various tumor (renal cell carcinoma, multiple myeloma, ovarian carcinoma, Kaposi sarcoma or EBV-associated post-transplant lymphoproliferative disorder) and chronic infection (M. tuberculosis, Human cytomegalovirus (HCMV), Human Immunodeficiency Virus (HIV), or hepatitis C virus (HCV) infection) settings $[30,60-66]$. However, until recently, 
the phenotypic and functional characteristics of PD- $1^{+} \mathrm{NK}$ cells were not evaluated in depth. Recent studies demonstrate that, like in T cells, PD- 1 is a critical negative regulator of NK cells. PD-1 ${ }^{+} \mathrm{NK}$ cells most often belong to the mature $\mathrm{CD} 56^{\mathrm{dim}} \mathrm{CD} 16^{+}$population, but exhibit variable modifications of their activating or inhibitory receptor repertoire depending on the clinical setting $[30,61,66]$. Thus, PD-1 expression is confined to a fully mature/terminally differentiated NKG2A- $\mathrm{KIR}^{+} \mathrm{CD} 57^{+}$ subpopulation in CMV-seropositive healthy subjects [66], but not in patients with Kaposi sarcoma [30]. In cancer patients, PD- $1^{+} \mathrm{NK}$ cells express markers of activation and apoptosis sensitivity, suggesting that they have experienced in vivo immune stimulation $[30,60]$. Such hypothesis is supported by in vitro experiments showing that PD-1 is induced upon prolonged stimulation by MHC class I-deficient tumor cells or by agonists of NK cell activating receptors [30,67], two conditions mimicking the tumor microenvironment. Notably, previous data demonstrated that NK cells are anergic in MHC-deficient tumor-bearing mice, although expression of PD-1 was not reported [68]. Irrespective of their phenotype, PD- $1^{+}$NK cells are functionally exhausted, exhibiting reduced proliferative capability, poor cytolytic activity and impaired cytokine production as compared with the PD-1 ${ }^{-} \mathrm{NK}$ cell population $[30,61,66,67]$. Moreover, in vitro blockade of the PD-1 pathway reverts the NK cell functional defects induced by PD-1/PDL-1 interactions, which confirms that PD-1 directly participates to NK cell exhaustion and is not simply a marker of chronic activation $[61,66]$.

Altogether, these findings indicate that, like in T cells, PD-1 represents a mediator of functional exhaustion in NK cells and may serve to blunt NK cell-mediated antitumor response. Therefore, releasing the PD-1 immune checkpoint in NK cells might help to circumvent tumor escape by enhancing NK-cell trafficking and effector functions against the tumor, as shown for CD8 T cells. In this context, it will be crucial to determine if NK cell functions are improved in cancer patients treated with inhibitors of the PD-1 pathway, as addressed in an ongoing clinical trial aiming to assess the effect of pembrozilumab on NK cell exhaustion (NCT03241927, Clinical trial.gov).

\section{Cytotoxic T Lymphocyte-Associated Antigen 4 (CTLA-4)}

Cytotoxic T lymphocyte-associated antigen 4 (CTLA-4) is another major immune checkpoint molecule induced on T cells upon activation, and negatively regulating their ongoing functions [69]. To exert its inhibitory effect, CTLA-4 competes with CD28 for the same ligands, B7-1 and B7-2, expressed by antigen-presenting cells [70]. Its crucial role in maintaining immune homeostasis is substantiated by the development of aggressive and fatal autoimmune diseases in animal models lacking CTLA-4 [71,72]. Numerous studies have reported an increased and persistent expression of CTLA-4 on antigen-specific T cells during chronic viral infections and tumors [73,74]. CTLA-4 expression clearly contributes to perpetuate tumor immune escape by continuously inhibiting effector functions of tumor-infiltrating lymphocytes. However, data on CTLA-4 expression on NK cells are scarce. CTLA-4 is induced on mouse IL-2-activated NK cells [75] and is expressed on splenic Kit ${ }^{+}$ and tumor-infiltrating NK cells in tumor-bearing mice $[75,76]$. CTLA-4 may be directly involved in inhibiting NK-cell IFN $\gamma$ production induced by mature dendritic cells [75]. Expression of CTLA-4 on human NK cells remains elusive, and the effect on NK cells of drugs targeting the CTLA-4 pathway in cancer patients has not been studied. It cannot be excluded that such therapeutic approaches could enhance NK cell effector function by an abscopal (out-of-target) effect. Indeed, anti-CTLA-4 therapy may target regulatory $\mathrm{T}$ (Treg) cells in vivo, thus unleashing NK cells from their suppressive effects [77,78]. Moreover, CTLA-4 blockade revivifies T cells and improves their IL-2 production [79]. In turn, IL-2 could ultimately reinvigorate NK-cell functions, especially when IL-2 becomes more available in the absence of Tregs [80]. Thus, one can speculate that anti-CTLA-4 therapy may also, at least indirectly, improve NK cell contribution to anti-tumor immune response.

\section{T-Cell Immunoglobulin and Mucin Domain 3 (Tim-3)}

T-cell immunoglobulin and mucin domain 3 (Tim-3) is a co-inhibitory receptor that was initially described on activated T cells $[81,82]$. Tim- 3 is also expressed in other immune populations such as 
NK, NKT and myeloid cells. In addition to galectin-9 [81], Tim-3 has been reported to bind other ligands such as phosphatidylserine exposed by apoptotic cells [83], the alarmin HMGB1 [84], and the carcinoembryonic antigen cell adhesion molecule 1 (CEACAM1) [85]. Tim-3 is considered to play an important role in immune tolerance as a negative regulator of proinflammatory responses to avoid excessive host damage [86]. Of note, Tim $-3^{+}$Foxp $3^{+}$Tregs display a higher suppressive function than Tim $3^{-}$Foxp $3^{+}$Tregs [87]. Tim-3 is also involved in mediating T-cell exhaustion during cancer and chronic viral infections [88,89]. Sustained expression of both PD-1 and Tim-3 defines highly exhausted CD8 T cells, suggesting cooperation between these two receptors to continuously inhibit $\mathrm{T}$ cell functions [89]. In numerous tumor models, blocking Tim-3 pathway rescues $\mathrm{T}$ cells from exhaustion, restores their functions, and leads to a better control of tumor growth [90-92].

Expression of Tim-3 on NK cells is well established, but its consequences are controversial. NK cells from healthy donors express Tim- 3 at steady state, mostly on the mature CD56 ${ }^{\mathrm{dim}} \mathrm{CD} 16^{+} \mathrm{NK}$ cells subset $[93,94]$. This expression is strongly upregulated upon cytokine activation, especially after stimulation with IL-12 + IL-18 or IL-15 + IL-12 [93,94]. Thus, Tim-3 expression on NK cells appears as a marker of maturation and/or activation of NK cells [93-95]. However, the role of the Tim-3 pathway in NK cell functions is confusing, as it was assigned both activating and inhibitory effects. While stimulation with anti-Tim-3 agonist antibodies curtails NK cell cytotoxic potential [93], engagement of Tim-3 by its cognate ligand Gal-9 enhances IFN $\gamma$ production but has no effect on NK cell cytotoxic ability [94]. Tim-3 blockade reduces NK cell-mediated killing of pancreatic cancer cell (PCC) lines [96]. However, in a context of chronic stimulation such as lung adenocarcinoma, advanced melanoma, or chronic hepatitis B, sustained Tim-3 expression defines a subset of functionally defective/exhausted NK cells, and Tim-3 blockade rescues NK cell functions [97-99]. Both Tim-3 and PD-1 are induced on mouse NK cells upon prolonged stimulation by MHC class I-deficient tumor cells. Tim- $3^{+}$PD- $1^{+} \mathrm{NK}$ cells are functionally exhausted, a defect reversible upon IL-21 stimulation [67].

Taken together, these data suggest that the role of Tim-3 in NK cells may vary according to the experimental or clinical setting. This is reminiscent of the dual role of another receptor, 2B4 (CD244), on NK cell activation. It is not excluded that in vivo, Tim-3 effect on NK cells depends on a functional threshold that fine-tunes the activity of Tim-3 signaling pathway. The promiscuous ligand specificity of Tim-3 may account for its controversial effect on NK cell function depending on the target cells considered, and / or the intensity and duration of Tim-3 receptor/ligand expression. The final effect may also depend on other factors including cytokine microenvironment. Thus, although manipulating the Tim-3 immune checkpoint on NK cells may appear promising to restore NK-cell mediated immune surveillance in cancer, further studies are warranted to better decipher Tim-3 effects in human NK cells.

\section{T Cell Immunoglobulin and ITIM Domain (TIGIT)}

TIGIT is an inhibitory receptor initially described on T and NK cells [100]. In NK cells, TIGIT competes with the DNAM-1 (CD226) activating receptor for their common ligands CD112 (PVRL2) and CD155 (PVR) expressed on many cancer cells [100-105]. TIGIT was shown to bind to its ligands with higher affinity than DNAM-1 [100-102]. TIGIT can directly dampen NK cell cytotoxicity and thus counterbalances the DNAM-1-mediated NK cell activation [101,102]. Recent data demonstrate that TIGIT sensitizes NK cells to immune suppression mediated by myeloid-derived suppressor cells (MDSC), an effect abrogated by TIGIT blockade [106]. Moreover, in vitro TIGIT blockade improves the anti-tumor effect of Trastuzumab (a recombinant humanized anti-HER2 monoclonal antibody used in HER2+ breast cancers), which partially relies on NK cell-mediated ADCC [105]. Thus, targeting the TIGIT axis may represent a promising additional tool to revivify NK cell functions in cancer patients.

\section{Lymphocyte Activation Gene-3 (LAG-3)}

LAG-3 is an inhibitory receptor presenting homologies with CD4 and can also bind to MHC class II molecules with higher affinity than CD4 [107-109]. LAG-3 expression was initially described on activated T and NK cells [109]. Further studies reported its expression in a wide range of immune cells 
including B cells, plasmacytoid dendritic cells, iNKT and Treg cells [110-114]. LAG-3 is able to directly inhibit $\mathrm{T}$ cell effector function $[9,16-18]$ while it promotes Treg suppressive functions $[110,112,115-118]$. Accumulating data suggest that LAG-3 is involved in T cell exhaustion in various cancer and chronic infection settings [119,120]. In vitro LAG-3 blockade improves T cell functions [121], and the combined blockade of PD-1 and LAG-3 synergistically rescues T cells from exhaustion in many cancers and chronic infection models [122-124]. Importantly, several ongoing clinical trials involve the use of anti-LAG-3 antibodies either alone or in combination with PD-1 blockade in various cancers (ClinicalTrials.gov). The direct impact of LAG-3 on NK cells functions was rarely investigated. NK cells from LAG-3 deficient mice exhibit a decreased capacity to eliminate certain tumor cell lines [125]. However, data in human NK cells are controversial. Blocking the LAG-3 pathway by anti-LAG-3 antibodies or soluble LAG-3 (able to bind MHC class II) had no effect on NK cell cytotoxic capability, although cytokine production was not investigated in this study [126]. More recently, low NK cell expression of inhibitory molecules, including LAG-3, was found to be associated with viral control in HIV infected patients [127]. However, the direct impact of LAG-3 expression on NK cells functions was not investigated. So far, the contribution of LAG-3 in NK cell functions remains elusive.

\section{Killer Cell Immunoglobulin-Like Receptors (KIRs)}

NK cells constitutively express inhibitory KIRs that recognize determinants shared by groups of MHC class I alleles. During NK cell development, the expression KIRs is variegated, and diverse NK cell subsets displaying various combinations of KIRs emerge in a given individual. Upon engagement with their cognate MHC-I ligands, KIRs provide an inhibitory signal that prevents NK cell activation towards healthy autologous cells, which constitutively express MHC class I molecules. Diminished expression of MHC class I (upon tumor transformation or viral infection) renders cells highly sensitive to NK-cell mediated killing [4,128-130]. In other words, a compromised interaction between KIRs and the corresponding MHC class I molecules is unable to deliver sufficient inhibitory signals to NK cells, thus allowing their activation. Notably, interactions between KIRs and their cognate MHC class I ligands during NK development are critical for the education or licensing process of NK cells, by which NK cells adapt their responsiveness and achieve self-tolerance [13].

In the field of hematologic malignancies, haplo-identical stem cell transplantation from a KIR ligand-mismatched donor favors NK cell alloreactivity thanks to the lack of relevant KIR-HLA class I interaction [24,131]. Infusions of KIR ligand-mismatched allogeneic NK cells prior to autologous stem cell transplantation for relapsed multiple myeloma showed encouraging results [132]. These data suggest that disinhibited NK cells can exert their anti-tumor functions with superior efficacy, which is associated with increased patients' survival.

Pharmacologic exploitation of inhibitory KIRs is possible and seems to be an attractive strategy to reinforce NK cell reactivity against tumor cells in order to achieve durable remission. Accumulating evidence point out the benefit of combining KIR blockade therapy to another immunotherapy relying on NK cell-mediated ADCC. For instance, in B cell lymphoma treatment, the efficacy of rituximab, an IgG1 anti-CD20 mAb, largely relies on NK cell-mediated ADCC $[23,25,133]$. However, Fc $\gamma$ RIIIA polymorphism clearly influences rituximab-dependent NK cell cytotoxicity, and patients with Fc $\gamma$ RIIIA polymorphism conferring a higher affinity for IgG1 have a better response rate [133,134]. A strategy to further improve rituximab responses is the use of KIR blockade therapy, which releases NK cells from the inhibition exerted by the high level of MHC-I expression on tumor cells. Ultimately, this strategy enhances rituximab-dependent cytotoxicity by NK cells [135]. Other mAbs therapies relying on NK cell-mediated ADCC could also benefit from such a combinatory strategy. Alternatively, combining KIR blockade with an immunomodulatory drug, such as lenalidomide known to enhance NK cell functions, could be of interest in the treatment of some hematologic malignancies such as multiple myeloma [136].

Anti-KIR therapy is already used (in combination with other agents) in several ongoing cancer clinical trials (Clinical trial.gov). Importantly, anti-KIR antibody administration seems to be well 
tolerated, with limited adverse effects $[136,137]$. Using pan-KIR blockade as a single anti-cancer therapy would probably not induce a sufficient clinical response, as shown in multiple myeloma [138]. Combinatory therapy seems to be a more promising choice.

\section{Natural Killer Cell Receptor Group 2 Member A (NKG2A)}

NKG2 lectin-like receptors are expressed as a heterodimer with C94 on NK cells and specifically recognize the non-classical MHC class I molecule, HLA-E. Upon interaction with HLA-E, CD94/NKG2A acts as an inhibitory receptor while its counter-receptor CD94/NKG2C delivers activating signals [139-141]. At contrast with classical MHC class I molecules, HLA-E binds a restricted subset of peptides derived from signal peptides of other MHC class I molecules including classical MHC class I and HLA-G [142]. Surface expression of HLA-E requires the presence of these peptides [143]. Therefore, expression level of HLA-E also mirrors the expression level of classical MHC class I molecules and HLA-G as well. Using CD94/NKG2A, NK cells indirectly monitor cell surface expression of both classical MHC class I molecules and HLA-G. Lack of HLA-E/NKG2A interaction triggers NK cell "missing-self" response. HLA-E is frequently upregulated on cells from many hematological malignancies or solid cancers [144-146]. Similar to KIR blockade, anti-NKG2A antibody can remove HLA-E-mediated NK cell inhibition, tip the balance to favor stimulation through NK cell activating receptors, and augment HLA-E accessibility for CD94/NKG2C. Monalizumab (IPH2201) is a therapeutic humanized IgG4 mAb that abrogates NKG2A receptor function. Monalizumab has already shown efficacy to strengthen NK cell responses against HLA-E overexpressing tumor cells in preclinical models [146], prompting its usage in various ongoing clinical trials including solid cancers and hematological malignancies (Clinical trial.gov).

\section{Concluding Remarks}

Dissecting the role of immune checkpoints in NK cells is crucial for the full understanding of the mode of action of therapies using checkpoint inhibitors. While several line of evidence indicates that PD-1 is a mediator of functional exhaustion in NK cells, the full understanding of the contribution of other immune checkpoints in the regulation of NK cell functions requires further investigation. It will be crucial to determine if unleashed NK cells help to improve anti-tumor response upon treatments with checkpoint inhibitors, but also if they may play a role in the inflammatory/autoimmune disorders that are associated with such treatments.

Acknowledgments: We thank R. Mallone (INSERM U1016 Cochin Institute) for reviewing the paper.

Author Contributions: Asma Beldi-Ferchiou and Sophie Caillat-Zucman wrote the paper.

Conflicts of Interest: The authors declare no conflict of interest.

\section{References}

1. Vivier, E.; Tomasello, E.; Baratin, M.; Walzer, T.; Ugolini, S. Functions of natural killer cells. Nat. Immunol. 2008, 9, 503-510. [CrossRef] [PubMed]

2. Lodoen, M.B.; Lanier, L.L. Natural killer cells as an initial defense against pathogens. Curr. Opin. Immunol. 2006, 18, 391-398. [CrossRef] [PubMed]

3. Cerwenka, A.; Lanier, L.L. Natural killer cells, viruses and cancer. Nat. Rev. Immunol. 2001, 1, 41-49. [CrossRef] [PubMed]

4. Sivori, S.; Carlomagno, S.; Pesce, S.; Moretta, A.; Vitale, M.; Marcenaro, E. TLR/NCR/KIR: Which one to use and when? Front. Immunol. 2014, 5. [CrossRef] [PubMed]

5. Raulet, D.H.; Guerra, N. Oncogenic stress sensed by the immune system: Role of natural killer cell receptors. Nat. Rev. Immunol. 2009, 9, 568-580. [CrossRef] [PubMed]

6. Del Zotto, G.; Marcenaro, E.; Vacca, P.; Sivori, S.; Pende, D.; Chiesa, M.D.; Moretta, F.; Ingegnere, T.; Mingari, M.C.; Moretta, A.; et al. Markers and function of human NK cells in normal and pathological conditions. Cytom. Part B Clin. Cytom. 2017, 92, 100-114. [CrossRef] [PubMed] 
7. Long, E.O.; Kim, H.S.; Liu, D.; Peterson, M.E.; Rajagopalan, S. Controlling natural killer cell responses: Integration of signals for activation and inhibition. Annu. Rev. Immunol. 2013, 31, 227-258. [CrossRef] [PubMed]

8. Orr, M.T.; Lanier, L.L. Natural killer cell education and tolerance. Cell 2010, 142, 847-856. [CrossRef] [PubMed]

9. Narni-Mancinelli, E.; Ugolini, S.; Vivier, E. Tuning the threshold of natural killer cell responses. Curr. Opin. Immunol. 2013, 25, 53-58. [CrossRef] [PubMed]

10. Raulet, D.H.; Vance, R.E. Self-tolerance of natural killer cells. Nat. Rev. Immunol. 2006, 6, 520-531. [CrossRef] [PubMed]

11. Raulet, D.H. Missing self recognition and self tolerance of natural killer (NK) cells. Semin. Immunol. 2006, 18, 145-150. [CrossRef] [PubMed]

12. Gasser, S.; Raulet, D.H. Activation and self-tolerance of natural killer cells. Immunol. Rev. 2006, 214, 130-142. [CrossRef] [PubMed]

13. Brodin, P.; Karre, K.; Hoglund, P. NK cell education: Not an on-off switch but a tunable rheostat. Trends Immunol. 2009, 30, 143-149. [CrossRef] [PubMed]

14. Yokoyama, W.M.; Kim, S. How do natural killer cells find self to achieve tolerance? Immunity 2006, 24, 249-257. [CrossRef] [PubMed]

15. Brusilovsky, M.; Rosental, B.; Shemesh, A.; Appel, M.Y.; Porgador, A. Human NK cell recognition of target cells in the prism of natural cytotoxicity receptors and their ligands. J. Immunotoxicol. 2012, 9, 267-274. [CrossRef] [PubMed]

16. Moretta, A.; Bottino, C.; Vitale, M.; Pende, D.; Cantoni, C.; Mingari, M.C.; Biassoni, R.; Moretta, L. Activating receptors and coreceptors involved in human natural killer cell-mediated cytolysis. Annu. Rev. Immunol. 2001, 19, 197-223. [CrossRef] [PubMed]

17. Fauriat, C.; Long, E.O.; Ljunggren, H.G.; Bryceson, Y.T. Regulation of human NK-cell cytokine and chemokine production by target cell recognition. Blood 2010, 115, 2167-2176. [CrossRef] [PubMed]

18. De Maria, A.; Bozzano, F.; Cantoni, C.; Moretta, L. Revisiting human natural killer cell subset function revealed cytolytic CD56(dim)CD16+ NK cells as rapid producers of abundant Ifn-gamma on activation. Proc. Natl. Acad. Sci. USA 2011, 108, 728-732. [CrossRef] [PubMed]

19. Cooper, M.A.; Fehniger, T.A.; Caligiuri, M.A. The biology of human natural killer-cell subsets. Trends Immunol. 2001, 22, 633-640. [CrossRef]

20. Deniz, G.; Erten, G.; Kucuksezer, U.C.; Kocacik, D.; Karagiannidis, C.; Aktas, E.; Akdis, C.A.; Akdis, M. Regulatory NK cells suppress antigen-specific T cell responses. J. Immunol. 2008, 180, 850-857. [CrossRef] [PubMed]

21. Morandi, B.; Mortara, L.; Carrega, P.; Cantoni, C.; Costa, G.; Accolla, R.S.; Mingari, M.C.; Ferrini, S.; Moretta, L.; Ferlazzo, G. NK cells provide helper signal for CD8+ T cells by inducing the expression of membrane-bound IL-15 on DCS. Int. Immunol. 2009, 21, 599-606. [CrossRef] [PubMed]

22. Vitale, M.; Della Chiesa, M.; Carlomagno, S.; Pende, D.; Arico, M.; Moretta, L.; Moretta, A. NK-dependent DC maturation is mediated by TNF- $\alpha$ and IFN $-\gamma$ released upon engagement of the NKP30 triggering receptor. Blood 2005, 106, 566-571. [CrossRef] [PubMed]

23. Awasthi, A.; Ayello, J.; van de Ven, C.; Elmacken, M.; Sabulski, A.; Barth, M.J.; Czuczman, M.S.; Islam, H.; Klein, C.; Cairo, M.S. Obinutuzumab (GA101) compared to rituximab significantly enhances cell death and antibody-dependent cytotoxicity and improves overall survival against CD20(+) rituximab-sensitive/-resistant burkitt lymphoma $(\mathrm{Bl})$ and precursor B-acute lymphoblastic leukaemia (pre-B-all): Potential targeted therapy in patients with poor risk CD20(+) Bl and pre-B-all. Br. J. Haematol. 2015, 171, 763-775. [PubMed]

24. Ruggeri, L.; Capanni, M.; Urbani, E.; Perruccio, K.; Shlomchik, W.D.; Tosti, A.; Posati, S.; Rogaia, D.; Frassoni, F.; Aversa, F.; et al. Effectiveness of donor natural killer cell alloreactivity in mismatched hematopoietic transplants. Science 2002, 295, 2097-2100. [CrossRef] [PubMed]

25. Wu, L.; Adams, M.; Carter, T.; Chen, R.; Muller, G.; Stirling, D.; Schafer, P.; Bartlett, J.B. Lenalidomide enhances natural killer cell and monocyte-mediated antibody-dependent cellular cytotoxicity of rituximab-treated CD20+ tumor cells. Clin. Cancer Res. 2008, 14, 4650-4657. [CrossRef] [PubMed]

26. Orange, J.S. Human natural killer cell deficiencies. Curr. Opin. Allergy Clin. Immunol. 2006, 6, $399-409$. [CrossRef] [PubMed] 
27. Orange, J.S. Natural killer cell deficiency. J. Allergy Clin. Immunol. 2013, 132, 515-526. [CrossRef] [PubMed]

28. Plonquet, A.; Haioun, C.; Jais, J.P.; Debard, A.L.; Salles, G.; Bene, M.C.; Feugier, P.; Rabian, C.; Casasnovas, O.; Labalette, M.; et al. Peripheral blood natural killer cell count is associated with clinical outcome in patients with AAIPI 2-3 diffuse large B-cell lymphoma. Ann. Oncol. 2007, 18, 1209-1215. [CrossRef] [PubMed]

29. Dupuy, S.; Lambert, M.; Zucman, D.; Choukem, S.P.; Tognarelli, S.; Pages, C.; Lebbe, C.; Caillat-Zucman, S. Human herpesvirus 8 (HHV8) sequentially shapes the NK cell repertoire during the course of asymptomatic infection and kaposi sarcoma. PLoS Pathog. 2012, 8, e1002486. [CrossRef] [PubMed]

30. Beldi-Ferchiou, A.; Lambert, M.; Dogniaux, S.; Vely, F.; Vivier, E.; Olive, D.; Dupuy, S.; Levasseur, F.; Zucman, D.; Lebbe, C.; et al. PD-1 mediates functional exhaustion of activated NK cells in patients with kaposi sarcoma. Oncotarget 2016, 7, 72961-72977. [CrossRef] [PubMed]

31. Sene, D.; Levasseur, F.; Abel, M.; Lambert, M.; Camous, X.; Hernandez, C.; Pene, V.; Rosenberg, A.R.; Jouvin-Marche, E.; Marche, P.N.; et al. Hepatitis c virus (HCV) evades NKG2D-dependent NK cell responses through NS5A-mediated imbalance of inflammatory cytokines. PLoS Pathog. 2010, 6, e1001184. [CrossRef] [PubMed]

32. Cerboni, C.; Neri, F.; Casartelli, N.; Zingoni, A.; Cosman, D.; Rossi, P.; Santoni, A.; Doria, M. Human immunodeficiency virus 1 NEF protein downmodulates the ligands of the activating receptor NKG2D and inhibits natural killer cell-mediated cytotoxicity. J. Gen. Virol. 2007, 88, 242-250. [CrossRef] [PubMed]

33. De Maria, A.; Fogli, M.; Costa, P.; Murdaca, G.; Puppo, F.; Mavilio, D.; Moretta, A.; Moretta, L. The impaired NK cell cytolytic function in viremic HIV-1 infection is associated with a reduced surface expression of natural cytotoxicity receptors (NKP46, NKP30 and NKP44). Eur. J. Immunol. 2003, 33, 2410-2418. [CrossRef] [PubMed]

34. Chretien, A.S.; Le Roy, A.; Vey, N.; Prebet, T.; Blaise, D.; Fauriat, C.; Olive, D. Cancer-induced alterations of NK-mediated target recognition: Current and investigational pharmacological strategies aiming at restoring NK-mediated anti-tumor activity. Front. Immunol. 2014, 5, 122. [CrossRef] [PubMed]

35. Wolchok, J.D.; Chiarion-Sileni, V.; Gonzalez, R.; Rutkowski, P.; Grob, J.J.; Cowey, C.L.; Lao, C.D.; Wagstaff, J.; Schadendorf, D.; Ferrucci, P.F.; et al. Overall survival with combined nivolumab and ipilimumab in advanced melanoma. N. Engl. J. Med. 2017, 377, 1345-1356. [CrossRef] [PubMed]

36. Topalian, S.L.; Hodi, F.S.; Brahmer, J.R.; Gettinger, S.N.; Smith, D.C.; McDermott, D.F.; Powderly, J.D.; Carvajal, R.D.; Sosman, J.A.; Atkins, M.B.; et al. Safety, activity, and immune correlates of anti-PD-1 antibody in cancer. N. Engl. J. Med. 2012, 366, 2443-2454. [CrossRef] [PubMed]

37. Robert, C.; Schachter, J.; Long, G.V.; Arance, A.; Grob, J.J.; Mortier, L.; Daud, A.; Carlino, M.S.; McNeil, C.; Lotem, M.; et al. Pembrolizumab versus ipilimumab in advanced melanoma. N. Engl. J. Med. 2015, 372, 2521-2532. [CrossRef] [PubMed]

38. Keir, M.E.; Butte, M.J.; Freeman, G.J.; Sharpe, A.H. PD-1 and its ligands in tolerance and immunity. Annu. Rev. Immunol. 2008, 26, 677-704. [CrossRef] [PubMed]

39. Agata, Y.; Kawasaki, A.; Nishimura, H.; Ishida, Y.; Tsubata, T.; Yagita, H.; Honjo, T. Expression of the PD-1 antigen on the surface of stimulated mouse $t$ and b lymphocytes. Int. Immunol. 1996, 8, 765-772. [CrossRef] [PubMed]

40. Bennett, F.; Luxenberg, D.; Ling, V.; Wang, I.M.; Marquette, K.; Lowe, D.; Khan, N.; Veldman, G.; Jacobs, K.A.; Valge-Archer, V.E.; et al. Program death-1 engagement upon TCR activation has distinct effects on costimulation and cytokine-driven proliferation: Attenuation of icos, IL-4, and IL-21, but not CD28, IL-7, and IL-15 responses. J. Immunol. 2003, 170, 711-718. [CrossRef] [PubMed]

41. Thibult, M.L.; Mamessier, E.; Gertner-Dardenne, J.; Pastor, S.; Just-Landi, S.; Xerri, L.; Chetaille, B.; Olive, D. PD-1 is a novel regulator of human B-cell activation. J. Immunol. 2013, 25, 129-137. [CrossRef] [PubMed]

42. Nishimura, H.; Okazaki, T.; Tanaka, Y.; Nakatani, K.; Hara, M.; Matsumori, A.; Sasayama, S.; Mizoguchi, A.; Hiai, H.; Minato, N.; et al. Autoimmune dilated cardiomyopathy in PD-1 receptor-deficient mice. Science 2001, 291, 319-322. [CrossRef] [PubMed]

43. Nishimura, H.; Nose, M.; Hiai, H.; Minato, N.; Honjo, T. Development of lupus-like autoimmune diseases by disruption of the PD-1 gene encoding an itim motif-carrying immunoreceptor. Immunity 1999, 11, 141-151. [CrossRef]

44. Prokunina, L.; Gunnarsson, I.; Sturfelt, G.; Truedsson, L.; Seligman, V.A.; Olson, J.L.; Seldin, M.F.; Criswell, L.A.; Alarcon-Riquelme, M.E. The systemic lupus erythematosus-associated PDCD1 polymorphism PD1.3A in lupus nephritis. Arthritis Rheum. 2004, 50, 327-328. [CrossRef] [PubMed] 
45. Kong, E.K.; Prokunina-Olsson, L.; Wong, W.H.; Lau, C.S.; Chan, T.M.; Alarcon-Riquelme, M.; Lau, Y.L. A new haplotype of PDCD1 is associated with rheumatoid arthritis in Hong Kong chinese. Arthritis Rheum. 2005, 52, 1058-1062. [CrossRef] [PubMed]

46. Kroner, A.; Mehling, M.; Hemmer, B.; Rieckmann, P.; Toyka, K.V.; Maurer, M.; Wiendl, H. A PD-1 polymorphism is associated with disease progression in multiple sclerosis. Ann. Neurol. 2005, 58, 50-57. [CrossRef] [PubMed]

47. Abdel-Wahab, N.; Shah, M.; Suarez-Almazor, M.E. Adverse events associated with immune checkpoint blockade in patients with cancer: A systematic review of case reports. PLoS ONE 2016, 11, e0160221. [CrossRef] [PubMed]

48. Cappelli, L.C.; Gutierrez, A.K.; Baer, A.N.; Albayda, J.; Manno, R.L.; Haque, U.; Lipson, E.J.; Bleich, K.B.; Shah, A.A.; Naidoo, J.; et al. Inflammatory arthritis and sicca syndrome induced by nivolumab and ipilimumab. Ann. Rheum. Dis. 2017, 76, 43-50. [CrossRef] [PubMed]

49. Parry, R.V.; Chemnitz, J.M.; Frauwirth, K.A.; Lanfranco, A.R.; Braunstein, I.; Kobayashi, S.V.; Linsley, P.S.; Thompson, C.B.; Riley, J.L. CTLA-4 and PD-1 receptors inhibit T-cell activation by distinct mechanisms. Mol. Cell. Biol. 2005, 25, 9543-9553. [CrossRef] [PubMed]

50. Chemnitz, J.M.; Parry, R.V.; Nichols, K.E.; June, C.H.; Riley, J.L. SHP-1 and SHP-2 associate with immunoreceptor tyrosine-based switch motif of programmed death 1 upon primary human $\mathrm{T}$ cell stimulation, but only receptor ligation prevents t cell activation. J. Immunol. 2004, 173, 945-954. [CrossRef] [PubMed]

51. Yokosuka, T.; Takamatsu, M.; Kobayashi-Imanishi, W.; Hashimoto-Tane, A.; Azuma, M.; Saito, T. Programmed cell death 1 forms negative costimulatory microclusters that directly inhibit T cell receptor signaling by recruiting phosphatase SHP2. J. Exp. Med. 2012, 209, 1201-1217. [CrossRef] [PubMed]

52. Sheppard, K.A.; Fitz, L.J.; Lee, J.M.; Benander, C.; George, J.A.; Wooters, J.; Qiu, Y.; Jussif, J.M.; Carter, L.L.; Wood, C.R.; et al. PD-1 inhibits t-cell receptor induced phosphorylation of the ZAP70/CD3zeta signalosome and downstream signaling to PKCtheta. FEBS Lett. 2004, 574, 37-41. [CrossRef] [PubMed]

53. Ahmadzadeh, M.; Johnson, L.A.; Heemskerk, B.; Wunderlich, J.R.; Dudley, M.E.; White, D.E.; Rosenberg, S.A. Tumor antigen-specific CD8 T cells infiltrating the tumor express high levels of PD-1 and are functionally impaired. Blood 2009, 114, 1537-1544. [CrossRef] [PubMed]

54. Okazaki, T.; Honjo, T. Rejuvenating exhausted t cells during chronic viral infection. Cell 2006, 124, 459-461. [CrossRef] [PubMed]

55. Lipson, E.J.; Sharfman, W.H.; Drake, C.G.; Wollner, I.; Taube, J.M.; Anders, R.A.; Xu, H.; Yao, S.; Pons, A.; Chen, L.; et al. Durable cancer regression off-treatment and effective reinduction therapy with an anti-PD-1 antibody. Clin. Cancer Res. 2013, 19, 462-468. [CrossRef] [PubMed]

56. Brahmer, J.R.; Tykodi, S.S.; Chow, L.Q.; Hwu, W.J.; Topalian, S.L.; Hwu, P.; Drake, C.G.; Camacho, L.H.; Kauh, J.; Odunsi, K.; et al. Safety and activity of anti-PD-11 antibody in patients with advanced cancer. N. Engl. J. Med. 2012, 366, 2455-2465. [CrossRef] [PubMed]

57. Beaver, J.A.; Theoret, M.R.; Mushti, S.; He, K.; Libeg, M.; Goldberg, K.; Sridhara, R.; McKee, A.E.; Keegan, P.; Pazdur, R. FDA approval of nivolumab for the first-line treatment of patients with BRAFV600 wild-type unresectable or metastatic melanoma. Clin. Cancer Res. 2017, 23, 3479-3483. [CrossRef] [PubMed]

58. Chang, W.S.; Kim, J.Y.; Kim, Y.J.; Kim, Y.S.; Lee, J.M.; Azuma, M.; Yagita, H.; Kang, C.Y. Cutting edge: Programmed death-1/programmed death ligand 1 interaction regulates the induction and maintenance of invariant NKT cell anergy. J. Immunol. 2008, 181, 6707-6710. [CrossRef] [PubMed]

59. Taylor, S.; Huang, Y.; Mallett, G.; Stathopoulou, C.; Felizardo, T.C.; Sun, M.A.; Martin, E.L.; Zhu, N.; Woodward, E.L.; Elias, M.S.; et al. PD-1 regulates KLRG1+ group 2 innate lymphoid cells. J. Exp. Med. 2017, 214, 1663-1678. [CrossRef] [PubMed]

60. MacFarlane, A.W.T.; Jillab, M.; Plimack, E.R.; Hudes, G.R.; Uzzo, R.G.; Litwin, S.; Dulaimi, E.; Al-Saleem, T.; Campbell, K.S. PD-1 expression on peripheral blood cells increases with stage in renal cell carcinoma patients and is rapidly reduced after surgical tumor resection. Cancer Immunol. Res. 2014, 2, 320-331. [CrossRef] [PubMed]

61. Wiesmayr, S.; Webber, S.A.; Macedo, C.; Popescu, I.; Smith, L.; Luce, J.; Metes, D. Decreased NKP46 and NKG2D and elevated PD-1 are associated with altered NK-cell function in pediatric transplant patients with ptld. Eur. J. Immunol. 2012, 42, 541-550. [CrossRef] [PubMed] 
62. Benson, D.M., Jr.; Bakan, C.E.; Mishra, A.; Hofmeister, C.C.; Efebera, Y.; Becknell, B.; Baiocchi, R.A.; Zhang, J.; Yu, J.; Smith, M.K.; et al. The PD-1/PD-11 axis modulates the natural killer cell versus multiple myeloma effect: A therapeutic target for CT-011, a novel monoclonal anti-PD-1 antibody. Blood 2010, 116, 2286-2294. [CrossRef] [PubMed]

63. Alvarez, I.B.; Pasquinelli, V.; Jurado, J.O.; Abbate, E.; Musella, R.M.; de la Barrera, S.S.; Garcia, V.E. Role played by the programmed death-1-programmed death ligand pathway during innate immunity against mycobacterium tuberculosis. J. Infect. Dis. 2010, 202, 524-532. [CrossRef] [PubMed]

64. Golden-Mason, L.; Klarquist, J.; Wahed, A.S.; Rosen, H.R. Cutting edge: Programmed death-1 expression is increased on immunocytes in chronic hepatitis c virus and predicts failure of response to antiviral therapy: Race-dependent differences. J. Immunol. 2008, 180, 3637-3641. [CrossRef] [PubMed]

65. Norris, S.; Coleman, A.; Kuri-Cervantes, L.; Bower, M.; Nelson, M.; Goodier, M.R. PD-1 expression on natural killer cells and CD8(+) T cells during chronic HIV-1 infection. Viral Immunol. 2012, 25, 329-332. [CrossRef] [PubMed]

66. Pesce, S.; Greppi, M.; Tabellini, G.; Rampinelli, F.; Parolini, S.; Olive, D.; Moretta, L.; Moretta, A.; Marcenaro, E. Identification of a subset of human natural killer cells expressing high levels of programmed death 1 : A phenotypic and functional characterization. J. Allergy Clin. Immunol. 2017, 139, 335-346.e3. [CrossRef] [PubMed]

67. Seo, H.; Jeon, I.; Kim, B.S.; Park, M.; Bae, E.A.; Song, B.; Koh, C.H.; Shin, K.S.; Kim, I.K.; Choi, K.; et al. IL-21-mediated reversal of NK cell exhaustion facilitates anti-tumour immunity in MHC class I-deficient tumours. Nat. Commun. 2017, 8, 15776. [CrossRef] [PubMed]

68. Ardolino, M.; Azimi, C.S.; Iannello, A.; Trevino, T.N.; Horan, L.; Zhang, L.; Deng, W.; Ring, A.M.; Fischer, S.; Garcia, K.C.; et al. Cytokine therapy reverses NK cell anergy in MHC-deficient tumors. J. Clin. Investig. 2014, 124, 4781-4794. [CrossRef] [PubMed]

69. Rudd, C.E.; Taylor, A.; Schneider, H. CD28 and CTLA-4 coreceptor expression and signal transduction. Immunol. Rev. 2009, 229, 12-26. [CrossRef] [PubMed]

70. Bour-Jordan, H.; Esensten, J.H.; Martinez-Llordella, M.; Penaranda, C.; Stumpf, M.; Bluestone, J.A. Intrinsic and extrinsic control of peripheral T-cell tolerance by costimulatory molecules of the CD28/B7 family. Immunol. Rev. 2011, 241, 180-205. [CrossRef] [PubMed]

71. Tivol, E.A.; Borriello, F.; Schweitzer, A.N.; Lynch, W.P.; Bluestone, J.A.; Sharpe, A.H. Loss of CTLA-4 leads to massive lymphoproliferation and fatal multiorgan tissue destruction, revealing a critical negative regulatory role of CTLA-4. Immunity 1995, 3, 541-547. [CrossRef]

72. Waterhouse, P.; Penninger, J.M.; Timms, E.; Wakeham, A.; Shahinian, A.; Lee, K.P.; Thompson, C.B.; Griesser, H.; Mak, T.W. Lymphoproliferative disorders with early lethality in mice deficient in CTLA-4. Science 1995, 270, 985-988. [CrossRef] [PubMed]

73. Cho, H.; Kang, H.; Lee, H.H.; Kim, C.W. Programmed cell death 1 (PD-1) and cytotoxic t lymphocyteassociated antigen 4 (CTLA-4) in viral hepatitis. Int. J. Mol. Sci. 2017, 18, 1517. [CrossRef] [PubMed]

74. Montler, R.; Bell, R.B.; Thalhofer, C.; Leidner, R.; Feng, Z.; Fox, B.A.; Cheng, A.C.; Bui, T.G.; Tucker, C.; Hoen, H.; et al. OX40, PD-1 and CTLA-4 are selectively expressed on tumor-infiltrating T cells in head and neck cancer. Clin. Transl. Immunol. 2016, 5, e70. [CrossRef] [PubMed]

75. Stojanovic, A.; Fiegler, N.; Brunner-Weinzierl, M.; Cerwenka, A. CTLA-4 is expressed by activated mouse NK cells and inhibits NK cell IFN- $\gamma$ production in response to mature dendritic cells. J. Immunol. 2014, 192, 4184-4191. [CrossRef] [PubMed]

76. Terme, M.; Ullrich, E.; Aymeric, L.; Meinhardt, K.; Coudert, J.D.; Desbois, M.; Ghiringhelli, F.; Viaud, S.; Ryffel, B.; Yagita, H.; et al. Cancer-induced immunosuppression: IL-18-elicited immunoablative NK cells. Cancer Res. 2012, 72, 2757-2767. [CrossRef] [PubMed]

77. Jie, H.B.; Schuler, P.J.; Lee, S.C.; Srivastava, R.M.; Argiris, A.; Ferrone, S.; Whiteside, T.L.; Ferris, R.L. CTLA-4(+) regulatory T cells increased in cetuximab-treated head and neck cancer patients suppress NK cell cytotoxicity and correlate with poor prognosis. Cancer Res. 2015, 75, 2200-2210. [CrossRef] [PubMed]

78. Romano, E.; Kusio-Kobialka, M.; Foukas, P.G.; Baumgaertner, P.; Meyer, C.; Ballabeni, P.; Michielin, O.; Weide, B.; Romero, P.; Speiser, D.E. Ipilimumab-dependent cell-mediated cytotoxicity of regulatory T cells ex vivo by nonclassical monocytes in melanoma patients. Proc. Natl. Acad. Sci. USA 2015, 112, 6140-6145. [CrossRef] [PubMed] 
79. Hannani, D.; Vetizou, M.; Enot, D.; Rusakiewicz, S.; Chaput, N.; Klatzmann, D.; Desbois, M.; Jacquelot, N.; Vimond, N.; Chouaib, S.; et al. Anticancer immunotherapy by CTLA-4 blockade: Obligatory contribution of IL-2 receptors and negative prognostic impact of soluble CD25. Cell Res. 2015, 25, 208-224. [CrossRef] [PubMed]

80. Kerdiles, Y.; Ugolini, S.; Vivier, E. T cell regulation of natural killer cells. J. Exp. Med. 2013, 210, $1065-1068$. [CrossRef] [PubMed]

81. Zhu, C.; Anderson, A.C.; Schubart, A.; Xiong, H.; Imitola, J.; Khoury, S.J.; Zheng, X.X.; Strom, T.B.; Kuchroo, V.K. The TIM-3 ligand galectin-9 negatively regulates thelper type 1 immunity. Nat. Immunol. 2005, 6, 1245-1252. [CrossRef] [PubMed]

82. Monney, L.; Sabatos, C.A.; Gaglia, J.L.; Ryu, A.; Waldner, H.; Chernova, T.; Manning, S.; Greenfield, E.A.; Coyle, A.J.; Sobel, R.A.; et al. TH1-specific cell surface protein TIM-3 regulates macrophage activation and severity of an autoimmune disease. Nature 2002, 415, 536-541. [CrossRef] [PubMed]

83. Nakayama, M.; Akiba, H.; Takeda, K.; Kojima, Y.; Hashiguchi, M.; Azuma, M.; Yagita, H.; Okumura, K. TIM-3 mediates phagocytosis of apoptotic cells and cross-presentation. Blood 2009, 113, 3821-3830. [CrossRef] [PubMed]

84. Chiba, S.; Baghdadi, M.; Akiba, H.; Yoshiyama, H.; Kinoshita, I.; Dosaka-Akita, H.; Fujioka, Y.; Ohba, Y.; Gorman, J.V.; Colgan, J.D.; et al. Tumor-infiltrating DCS suppress nucleic acid-mediated innate immune responses through interactions between the receptor TIM-3 and the alarmin HMGB1. Nat. Immunol. 2012, 13, 832-842. [CrossRef] [PubMed]

85. Huang, Y.H.; Zhu, C.; Kondo, Y.; Anderson, A.C.; Gandhi, A.; Russell, A.; Dougan, S.K.; Petersen, B.S.; Melum, E.; Pertel, T.; et al. CEACAM1 regulates TIM-3-mediated tolerance and exhaustion. Nature 2015, 517, 386-390. [CrossRef] [PubMed]

86. Anderson, A.C.; Joller, N.; Kuchroo, V.K. LAG-3, TIM-3, and TIGIT: Co-inhibitory receptors with specialized functions in immune regulation. Immunity 2016, 44, 989-1004. [CrossRef] [PubMed]

87. Sun, H.; Gao, W.; Pan, W.; Zhang, Q.; Wang, G.; Feng, D.; Geng, X.; Yan, X.; Li, S. TIM3 ${ }^{+}$FOXP3 ${ }^{+}$treg cells are potent inhibitors of effector T cells and are suppressed in rheumatoid arthritis. Inflammation 2017, 40, 1342-1350. [CrossRef] [PubMed]

88. Linedale, R.; Schmidt, C.; King, B.T.; Ganko, A.G.; Simpson, F.; Panizza, B.J.; Leggatt, G.R. Elevated frequencies of CD8 T cells expressing PD-1, CTLA-4 and TIM-3 within tumour from perineural squamous cell carcinoma patients. PLoS ONE 2017, 12, e0175755. [CrossRef] [PubMed]

89. Jin, H.T.; Anderson, A.C.; Tan, W.G.; West, E.E.; Ha, S.J.; Araki, K.; Freeman, G.J.; Kuchroo, V.K.; Ahmed, R. Cooperation of TIM-3 and PD-1 in CD8 T-cell exhaustion during chronic viral infection. Proc. Natl. Acad. Sci. USA 2010, 107, 14733-14738. [CrossRef] [PubMed]

90. Fourcade, J.; Sun, Z.; Benallaoua, M.; Guillaume, P.; Luescher, I.F.; Sander, C.; Kirkwood, J.M.; Kuchroo, V.; Zarour, H.M. Upregulation of TIM-3 and PD-1 expression is associated with tumor antigen-specific CD8+ T cell dysfunction in melanoma patients. J. Exp. Med. 2010, 207, 2175-2186. [CrossRef] [PubMed]

91. Liu, J.; Zhang, S.; Hu, Y.; Yang, Z.; Li, J.; Liu, X.; Deng, L.; Wang, Y.; Zhang, X.; Jiang, T.; et al. Targeting PD-1 and TIM-3 pathways to reverse CD8 T-cell exhaustion and enhance ex vivo T-cell responses to autologous dendritic/tumor vaccines. J. Immunother. 2016, 39, 171-180. [CrossRef] [PubMed]

92. Sakuishi, K.; Apetoh, L.; Sullivan, J.M.; Blazar, B.R.; Kuchroo, V.K.; Anderson, A.C. Targeting TIM-3 and PD-1 pathways to reverse T cell exhaustion and restore anti-tumor immunity. J. Exp. Med. 2010, 207, 2187-2194. [CrossRef] [PubMed]

93. Ndhlovu, L.C.; Lopez-Verges, S.; Barbour, J.D.; Jones, R.B.; Jha, A.R.; Long, B.R.; Schoeffler, E.C.; Fujita, T.; Nixon, D.F.; Lanier, L.L. TIM-3 marks human natural killer cell maturation and suppresses cell-mediated cytotoxicity. Blood 2012, 119, 3734-3743. [CrossRef] [PubMed]

94. Gleason, M.K.; Lenvik, T.R.; McCullar, V.; Felices, M.; O’Brien, M.S.; Cooley, S.A.; Verneris, M.R.; Cichocki, F.; Holman, C.J.; Panoskaltsis-Mortari, A.; et al. TIM-3 is an inducible human natural killer cell receptor that enhances interferon gamma production in response to galectin-9. Blood 2012, 119, 3064-3072. [CrossRef] [PubMed]

95. Gallois, A.; Silva, I.; Osman, I.; Bhardwaj, N. Reversal of natural killer cell exhaustion by TIM-3 blockade. Oncoimmunology 2014, 3, e946365. [CrossRef] [PubMed] 
96. Van Audenaerde, J.R.M.; de Waele, J.; Marcq, E.; van Loenhout, J.; Lion, E.; van den Bergh, J.M.J.; Jesenofsky, R.; Masamune, A.; Roeyen, G.; Pauwels, P.; et al. Interleukin-15 stimulates natural killer cell-mediated killing of both human pancreatic cancer and stellate cells. Oncotarget 2017, 8, 56968-56979. [CrossRef] [PubMed]

97. Ju, Y.; Hou, N.; Meng, J.; Wang, X.; Zhang, X.; Zhao, D.; Liu, Y.; Zhu, F.; Zhang, L.; Sun, W.; et al. T cell immunoglobulin- and mucin-domain-containing molecule-3 (TIM-3) mediates natural killer cell suppression in chronic hepatitis B. J. Hepatol. 2010, 52, 322-329. [CrossRef] [PubMed]

98. Da Silva, I.P.; Gallois, A.; Jimenez-Baranda, S.; Khan, S.; Anderson, A.C.; Kuchroo, V.K.; Osman, I.; Bhardwaj, N. Reversal of NK-cell exhaustion in advanced melanoma by TIM-3 blockade. Cancer Immunol. Res. 2014, 2, 410-422. [CrossRef] [PubMed]

99. Xu, L.; Huang, Y.; Tan, L.; Yu, W.; Chen, D.; Lu, C.; He, J.; Wu, G.; Liu, X.; Zhang, Y. Increased TIM-3 expression in peripheral NK cells predicts a poorer prognosis and TIM-3 blockade improves NK cell-mediated cytotoxicity in human lung adenocarcinoma. Int. Immunopharmacol. 2015, 29, 635-641. [CrossRef] [PubMed]

100. Yu, X.; Harden, K.; Gonzalez, L.C.; Francesco, M.; Chiang, E.; Irving, B.; Tom, I.; Ivelja, S.; Refino, C.J.; Clark, H.; et al. The surface protein tigit suppresses $\mathrm{T}$ cell activation by promoting the generation of mature immunoregulatory dendritic cells. Nat. Immunol. 2009, 10, 48-57. [CrossRef] [PubMed]

101. Stanietsky, N.; Simic, H.; Arapovic, J.; Toporik, A.; Levy, O.; Novik, A.; Levine, Z.; Beiman, M.; Dassa, L.; Achdout, H.; et al. The interaction of TIGIT with PVR and PVRL2 inhibits human NK cell cytotoxicity. Proc. Natl. Acad. Sci. USA 2009, 106, 17858-17863. [CrossRef] [PubMed]

102. Stanietsky, N.; Rovis, T.L.; Glasner, A.; Seidel, E.; Tsukerman, P.; Yamin, R.; Enk, J.; Jonjic, S.; Mandelboim, O. Mouse tigit inhibits NK-cell cytotoxicity upon interaction with PVR. Eur. J. Immunol. 2013, 43, 2138-2150. [CrossRef] [PubMed]

103. Bottino, C.; Castriconi, R.; Pende, D.; Rivera, P.; Nanni, M.; Carnemolla, B.; Cantoni, C.; Grassi, J.; Marcenaro, S.; Reymond, N.; et al. Identification of PVR (CD155) and nectin-2 (CD112) as cell surface ligands for the human DNAM-1 (CD226) activating molecule. J. Exp. Med. 2003, 198, 557-567. [CrossRef] [PubMed]

104. Iguchi-Manaka, A.; Kai, H.; Yamashita, Y.; Shibata, K.; Tahara-Hanaoka, S.; Honda, S.; Yasui, T.; Kikutani, H.; Shibuya, K.; Shibuya, A. Accelerated tumor growth in mice deficient in DNAM-1 receptor. J. Exp. Med. 2008, 205, 2959-2964. [CrossRef] [PubMed]

105. Xu, F.; Sunderland, A.; Zhou, Y.; Schulick, R.D.; Edil, B.H.; Zhu, Y. Blockade of CD112R and TIGIT signaling sensitizes human natural killer cell functions. Cancer Immunol. Immunother. CII 2017. [CrossRef] [PubMed]

106. Sarhan, D.; Cichocki, F.; Zhang, B.; Yingst, A.; Spellman, S.R.; Cooley, S.; Verneris, M.R.; Blazar, B.R.; Miller, J.S. Adaptive nk cells with low TIGIT expression are inherently resistant to myeloid-derived suppressor cells. Cancer Res. 2016, 76, 5696-5706. [CrossRef] [PubMed]

107. Triebel, F.; Jitsukawa, S.; Baixeras, E.; Roman-Roman, S.; Genevee, C.; Viegas-Pequignot, E.; Hercend, T. LAG-3, a novel lymphocyte activation gene closely related to CD4. J. Exp. Med. 1990, 171, 1393-1405. [CrossRef] [PubMed]

108. Huard, B.; Prigent, P.; Tournier, M.; Bruniquel, D.; Triebel, F. CD4/major histocompatibility complex class II interaction analyzed with CD4- and lymphocyte activation gene-3 (LAG-3)-ig fusion proteins. Eur. J. Immunol. 1995, 25, 2718-2721. [CrossRef] [PubMed]

109. Baixeras, E.; Huard, B.; Miossec, C.; Jitsukawa, S.; Martin, M.; Hercend, T.; Auffray, C.; Triebel, F.; Piatier-Tonneau, D. Characterization of the lymphocyte activation gene 3-encoded protein. A new ligand for human leukocyte antigen class ii antigens. J. Exp. Med. 1992, 176, 327-337. [CrossRef] [PubMed]

110. Xu, F.; Liu, J.; Liu, D.; Liu, B.; Wang, M.; Hu, Z.; Du, X.; Tang, L.; He, F. Lsectin expressed on melanoma cells promotes tumor progression by inhibiting antitumor T-cell responses. Cancer Res. 2014, 74, 3418-3428. [CrossRef] [PubMed]

111. Workman, C.J.; Wang, Y.; El Kasmi, K.C.; Pardoll, D.M.; Murray, P.J.; Drake, C.G.; Vignali, D.A. LAG-3 regulates plasmacytoid dendritic cell homeostasis. J. Immunol. 2009, 182, 1885-1891. [CrossRef] [PubMed]

112. Huang, C.T.; Workman, C.J.; Flies, D.; Pan, X.; Marson, A.L.; Zhou, G.; Hipkiss, E.L.; Ravi, S.; Kowalski, J.; Levitsky, H.I.; et al. Role of LAG-3 in regulatory T cells. Immunity 2004, 21, 503-513. [CrossRef] [PubMed]

113. Juno, J.A.; Stalker, A.T.; Waruk, J.L.; Oyugi, J.; Kimani, M.; Plummer, F.A.; Kimani, J.; Fowke, K.R. Elevated expression of LAG-3, but not PD-1, is associated with impaired INKT cytokine production during chronic HIV-1 infection and treatment. Retrovirology 2015, 12. [CrossRef] [PubMed] 
114. Kisielow, M.; Kisielow, J.; Capoferri-Sollami, G.; Karjalainen, K. Expression of lymphocyte activation gene 3 (LAG-3) on B cells is induced by T cells. Eur. J. Immunol. 2005, 35, 2081-2088. [CrossRef] [PubMed]

115. Hannier, S.; Triebel, F. The MHC class II ligand lymphocyte activation gene-3 is co-distributed with CD8 and CD3-TCR molecules after their engagement by MAB or peptide-MHC class I complexes. Int. Immunol. 1999, 11, 1745-1752. [CrossRef] [PubMed]

116. Workman, C.J.; Dugger, K.J.; Vignali, D.A. Cutting edge: Molecular analysis of the negative regulatory function of lymphocyte activation gene-3. J. Immunol. 2002, 169, 5392-5395. [CrossRef] [PubMed]

117. Sierro, S.; Romero, P.; Speiser, D.E. The CD4-like molecule LAG-3, biology and therapeutic applications. Expert Opin. Ther. Targets 2011, 15, 91-101. [CrossRef] [PubMed]

118. Camisaschi, C.; Casati, C.; Rini, F.; Perego, M.; de Filippo, A.; Triebel, F.; Parmiani, G.; Belli, F.; Rivoltini, L.; Castelli, C. LAG-3 expression defines a subset of CD4(+)CD25(high)FOXP3(+) regulatory $\mathrm{T}$ cells that are expanded at tumor sites. J. Immunol. 2010, 184, 6545-6551. [CrossRef] [PubMed]

119. Ye, B.; Li, X.; Dong, Y.; Wang, Y.; Tian, L.; Lin, S.; Liu, X.; Kong, H.; Chen, Y. Increasing LAG-3 expression suppresses T-cell function in chronic hepatitis B: A balance between immunity strength and liver injury extent. Medicine 2017, 96, e5275. [CrossRef] [PubMed]

120. Matsuzaki, J.; Gnjatic, S.; Mhawech-Fauceglia, P.; Beck, A.; Miller, A.; Tsuji, T.; Eppolito, C.; Qian, F.; Lele, S.; Shrikant, P.; et al. Tumor-infiltrating NY-ESO-1-specific CD8+ T cells are negatively regulated by LAG-3 and PD-1 in human ovarian cancer. Proc. Natl. Acad. Sci. USA 2010, 107, 7875-7880. [CrossRef] [PubMed]

121. Macon-Lemaitre, L.; Triebel, F. The negative regulatory function of the lymphocyte-activation gene- 3 co-receptor (CD223) on human T cells. Immunology 2005, 115, 170-178. [CrossRef] [PubMed]

122. Blackburn, S.D.; Shin, H.; Haining, W.N.; Zou, T.; Workman, C.J.; Polley, A.; Betts, M.R.; Freeman, G.J.; Vignali, D.A.; Wherry, E.J. Coregulation of CD8+ T cell exhaustion by multiple inhibitory receptors during chronic viral infection. Nat. Immunol. 2009, 10, 29-37. [CrossRef] [PubMed]

123. Freeman, G.J.; Sharpe, A.H. A new therapeutic strategy for malaria: Targeting $\mathrm{T}$ cell exhaustion. Nat. Immunol. 2012, 13, 113-115. [CrossRef] [PubMed]

124. Woo, S.R.; Turnis, M.E.; Goldberg, M.V.; Bankoti, J.; Selby, M.; Nirschl, C.J.; Bettini, M.L.; Gravano, D.M.; Vogel, P.; Liu, C.L.; et al. Immune inhibitory molecules LAG-3 and PD-1 synergistically regulate T-cell function to promote tumoral immune escape. Cancer Res. 2012, 72, 917-927. [CrossRef] [PubMed]

125. Miyazaki, T.; Dierich, A.; Benoist, C.; Mathis, D. Independent modes of natural killing distinguished in mice lacking LAG3. Science 1996, 272, 405-408. [CrossRef] [PubMed]

126. Huard, B.; Tournier, M.; Triebel, F. LAG-3 does not define a specific mode of natural killing in human. Immunol. Lett. 1998, 61, 109-112. [CrossRef]

127. Taborda, N.A.; Hernandez, J.C.; Lajoie, J.; Juno, J.A.; Kimani, J.; Rugeles, M.T.; Fowke, K.R. Short communication: Low expression of activation and inhibitory molecules on NK cells and CD4(+) T cells is associated with viral control. AIDS Res. Hum. Retrovir. 2015, 31, 636-640. [CrossRef] [PubMed]

128. Long, E.O.; Barber, D.F.; Burshtyn, D.N.; Faure, M.; Peterson, M.; Rajagopalan, S.; Renard, V.; Sandusky, M.; Stebbins, C.C.; Wagtmann, N.; et al. Inhibition of natural killer cell activation signals by killer cell immunoglobulin-like receptors (CD158). Immunol. Rev. 2001, 181, 223-233. [CrossRef] [PubMed]

129. Yusa, S.; Campbell, K.S. SRC homology region 2-containing protein tyrosine phosphatase-2 (SHP-2) can play a direct role in the inhibitory function of killer cell IG-like receptors in human NK cells. J. Immunol. 2003, 170, 4539-4547. [CrossRef] [PubMed]

130. Karre, K. Natural killer cell recognition of missing self. Nat. Immunol. 2008, 9, 477-480. [CrossRef] [PubMed]

131. Velardi, A.; Ruggeri, L.; Alessandro; Moretta; Moretta, L. NK cells: A lesson from mismatched hematopoietic transplantation. Trends Immunol. 2002, 23, 438-444. [CrossRef]

132. Shi, J.; Tricot, G.; Szmania, S.; Rosen, N.; Garg, T.K.; Malaviarachchi, P.A.; Moreno, A.; Dupont, B.; Hsu, K.C.; Baxter-Lowe, L.A.; et al. Infusion of haplo-identical killer immunoglobulin-like receptor ligand mismatched NK cells for relapsed myeloma in the setting of autologous stem cell transplantation. Br. J. Haematol. 2008, 143, 641-653. [CrossRef] [PubMed]

133. Cartron, G.; Dacheux, L.; Salles, G.; Solal-Celigny, P.; Bardos, P.; Colombat, P.; Watier, H. Therapeutic activity of humanized anti-CD20 monoclonal antibody and polymorphism in IGG FC receptor FC $\gamma$ RIIIA gene. Blood 2002, 99, 754-758. [CrossRef] [PubMed] 
134. Weng, W.K.; Levy, R. Two immunoglobulin g fragment c receptor polymorphisms independently predict response to rituximab in patients with follicular lymphoma. J. Clin. Oncol. 2003, 21, 3940-3947. [CrossRef] [PubMed]

135. Kohrt, H.E.; Thielens, A.; Marabelle, A.; Sagiv-Barfi, I.; Sola, C.; Chanuc, F.; Fuseri, N.; Bonnafous, C.; Czerwinski, D.; Rajapaksa, A.; et al. Anti-KIR antibody enhancement of anti-lymphoma activity of natural killer cells as monotherapy and in combination with anti-CD20 antibodies. Blood 2014, 123, 678-686. [CrossRef] [PubMed]

136. Benson, D.M., Jr.; Cohen, A.D.; Jagannath, S.; Munshi, N.C.; Spitzer, G.; Hofmeister, C.C.; Efebera, Y.A.; Andre, P.; Zerbib, R.; Caligiuri, M.A. A phase I trial of the anti-KIR antibody IPH2101 and lenalidomide in patients with relapsed/refractory multiple myeloma. Clin. Cancer Res. 2015, 21, 4055-4061. [CrossRef] [PubMed]

137. Benson, D.M., Jr.; Hofmeister, C.C.; Padmanabhan, S.; Suvannasankha, A.; Jagannath, S.; Abonour, R.; Bakan, C.; Andre, P.; Efebera, Y.; Tiollier, J.; et al. A phase 1 trial of the anti-KIR antibody IPH2101 in patients with relapsed/refractory multiple myeloma. Blood 2012, 120, 4324-4333. [CrossRef] [PubMed]

138. Korde, N.; Carlsten, M.; Lee, M.J.; Minter, A.; Tan, E.; Kwok, M.; Manasanch, E.; Bhutani, M.; Tageja, N.; Roschewski, M.; et al. A phase Ii trial of pan-KIR2D blockade with IPH2101 in smoldering multiple myeloma. Haematologica 2014, 99, e81-e83. [CrossRef] [PubMed]

139. Borrego, F.; Ulbrecht, M.; Weiss, E.H.; Coligan, J.E.; Brooks, A.G. Recognition of human histocompatibility leukocyte antigen (HLA)-e complexed with hla class I signal sequence-derived peptides by CD94/NKG2 confers protection from natural killer cell-mediated lysis. J. Exp. Med. 1998, 187, 813-818. [CrossRef] [PubMed]

140. Lee, N.; Llano, M.; Carretero, M.; Ishitani, A.; Navarro, F.; Lopez-Botet, M.; Geraghty, D.E. HLA-E is a major ligand for the natural killer inhibitory receptor CD94/NKG2A. Proc. Natl. Acad. Sci. USA 1998, 95, 5199-5204. [CrossRef] [PubMed]

141. Llano, M.; Lee, N.; Navarro, F.; Garcia, P.; Albar, J.P.; Geraghty, D.E.; Lopez-Botet, M. HLA-E-bound peptides influence recognition by inhibitory and triggering CD94/NKG2 receptors: Preferential response to an HLA-G-derived nonamer. Eur. J. Immunol. 1998, 28, 2854-2863. [CrossRef]

142. Braud, V.; Jones, E.Y.; McMichael, A. The human major histocompatibility complex class IB molecule HLA-E binds signal sequence-derived peptides with primary anchor residues at positions 2 and 9. Eur. J. Immunol. 1997, 27, 1164-1169. [CrossRef] [PubMed]

143. Lee, N.; Goodlett, D.R.; Ishitani, A.; Marquardt, H.; Geraghty, D.E. HLA-E surface expression depends on binding of tap-dependent peptides derived from certain HLA class I signal sequences. J. Immunol. 1998, 160, 4951-4960. [PubMed]

144. Costa Arantes, D.A.; Goncalves, A.S.; Jham, B.C.; Duarte, E.C.B.; de Paula, E.C.; de Paula, H.M.; Mendonca, E.F.; Batista, A.C. Evaluation of HLA-G, HLA-E, and PD-11 proteins in oral osteosarcomas. Oral Surg. Oral Med. Oral Pathol. Oral Radiol. 2017, 123, e188-e196. [CrossRef] [PubMed]

145. Huang, R.; Zhang, D.; Li, F.; Xiao, Z.; Wu, M.; Shi, D.; Xiang, P.; Bao, Z. Loss of fas expression and high expression of HLA-E promoting the immune escape of early colorectal cancer cells. Oncol. Lett. 2017, 13, 3379-3386. [CrossRef] [PubMed]

146. McWilliams, E.M.; Mele, J.M.; Cheney, C.; Timmerman, E.A.; Fiazuddin, F.; Strattan, E.J.; Mo, X.; Byrd, J.C.; Muthusamy, N.; Awan, F.T. Therapeutic CD94/NKG2A blockade improves natural killer cell dysfunction in chronic lymphocytic leukemia. Oncoimmunology 2016, 5, e1226720. [CrossRef] [PubMed]

(C) 2017 by the authors. Licensee MDPI, Basel, Switzerland. This article is an open access article distributed under the terms and conditions of the Creative Commons Attribution (CC BY) license (http://creativecommons.org/licenses/by/4.0/). 